\title{
Funding Postsecondary Education: A Full Tuition, Private Sector, Income Contingent Repayment Plan
}

\section{L.C. MCDONOUGH}

Royal Military College of Canada

\section{R.E. WRIGHT}

Nanyang Technological University, Singapore

\section{Abstract}

This study proposes and analyses the feasibility of a private sector ICR in which investments in human capital are accorded the tax treatment typical of fixed capital investments. Under this proposal, income-contingent repayment loans issued and administered by the private sector would cover both the full tuition costs and living expenses of students attending Postsecondary Education (PSE) institutions. The public sector would guarantee the loans, as well as provide relevant information to the private sector lenders as required.

Simulations suggest that the student and public sector shares in the proposed full fee and expense plan would be approximately the same as those under the current financing system with students' fees set at $50 \%$ of . full tuition. The proposed plan promises to eliminate virtually all accessibility problems related to financial constraints. Moreover, the incentive structures attendant to the proposed ICR are consistent with the "coherent learning system" advocated by the Economic Council of Canada. 


\section{Résumé}

Cette étude porte sur la faisabilité d'un plan de prêts avec remboursement à la source, déduit du revenu, dans lequel les investissements en capital humain recevraient le traitement propre aux taxations sur investissements à capital fixe. Selon ce plan, les prêts fournis et administrés par le secteur privé couvriraient les frais d'inscription ainsi que les frais d'hébergement d'étudiants inscrits à des institutions d'enseignement postsecondaire. Le secteur public garantirait les prêts et aurait la responsabilité de fournir les informations utiles aux prêteurs du secteur privé. La plausibilité de ce plan est examinée eu égard à la situation canadienne. Les simulations effectuées indiquent que le financement des étudiants et du secteur public pourraient être approximativement semblables au taux de répartition actuel si les frais d'enseignement se montaient à environ 50\% de coûts totaux. Ce plan prometteur pourrait éliminer tous les problèmes d'accès associés au manque de ressources financières des étudiants potentiels. De plus, le système d'encouragement prévu s'accorde au concept de cohérence du système d'apprentissage que recommande le Conseil économique du Canada.

\section{Introduction}

Income Contingent Repayment (ICR) plans have been discussed for decades and have been implemented in a number of countries. ${ }^{1}$ In Canada, an ICR was among the recommendations of the Macdonald Royal Commission (1985); a modest ICR plan for the Ministry of Ontario Universities was empirically investigated by Stager and Derkach (1992); and more recently, the Axworthy Green Paper (1994) discussed an ICR plan for Canada. For all that, the likelihood of a comprehensive Canadian ICR still seems remote. The Canada Social and Health Transfer appears to have limited program-oriented Federal initiatives in favour of block grants to provinces. Budgetary constraints in postsecondary education (PSE) are being met by increased tuition fees and declining enrollment. It seems rather odd that, while there is general agreement that funding mechanisms must be changed (Maxwell, 1994), little seems to be changing.

This paper proposes and analyses the feasibility of a private sector loan plan that includes an income contingent repayment scheme. The ICR loans would cover the full cost of tuition and living expenses which 
represent the PSE investment in human capital. Loan repayments are treated as capital expenditures and are fully tax deductible. The ICR feature requires that the public sector guarantee PSE investment loans thus providing tangible security for the loans. The public sector is also assigned the role of information management in which private sector lenders are advised of the income and location of borrowers as required. This plan ensures financial accessibility for students, helps to ensure adequate funding for PSE institutions, and creates incentive structures directed toward enhancing the quality and efficiency of PSE services.

In the next section we discuss the elements and rationale for a Private Income Contingent Repayment Plan (PP). The feasibility of the plan is evaluated using data from the Statistics Canada 1992 Survey of 1990 Graduates as well as age/income data from the 1986 census. The third section discusses several issues important to the concept and design of an Income Contingent Repayment Plan, particularly as they apply to the proposed PP. The fourth section discusses incentive effects of the PP and its relationship to a more comprehensive view of PSE. The final section summarizes the conclusions.

\section{Elements of a Private Income Contingent Plan}

\section{An ICR and Human Capital}

An ICR plan is typically considered to consist of a source of funds established by the government from which qualified students can obtain tuition loans. Repayment of a loan is based on the student's income after graduation and may be in the form of an additional tax. Repayment would be income contingent in that the additional tax rate (or repayment rate) would rise with income and there would be a minimum income below which no payments would be required.

There are a number of benefits associated with such a plan. Perhaps the most important stems from such a plan's simplicity. Payments might be deducted at source according to some prescribed tax rate for an extended period, for example up to 25 years. Accessibility need not be constrained in any way by the financial status of the student. Such a program promises considerable cost savings relative to the current student loan programs. In this proposal, interest accumulates on advances and collection and default costs are minimized since the individual is tracked through the tax system. Evaluation of student requirements is relatively 
simple as they are based on tuition requirements plus a living allowance. Finally, fee increases, whether a result of an institutional policy change or a reduction in public sector subsidies, would not impede access if the ICR were sufficiently flexible to accommodate such changes.

A major reason for the lack of action in PSE funding stems from the fact that there is considerable concern over the details of such plans. However, there are some basic economic features of PSE which underlie the recommendations for ICR plans:

1. Expenditures on PSE are investments in capital, human capital.

2. The intangibility of the asset produced by PSE precludes a broad market specializing in PSE capital.

3. The lender in an ICR plan requires income information about the borrower.

Human capital investment differs from physical capital investment. "To the extent that schooling increases the future earnings of the student, it has the attributes of an investment. But the human capital thus created cannot be sold as can nonhuman capital." (Shultz, 1963, p. 4) The key difference between human and physical capital stems from the intangibility of the former. During the creation of human capital there is no physical chattel available that can be used as security to acquire financing, nor is there any easy way to estimate an intermediate value (workin-process). Moreover, the value of the human capital is, to a large extent, a function of the intellect and personality of the person in whom it resides. No extensive market currently exists for risk bearing during the creation of this highly intangible human capital, and, as a result, lending institutions are unable to estimate their potential losses. The income stream as a result of the investment in human capital does not begin until after some gestation period and is, in many cases, not a smooth or easily predictable path.

These characteristics of investments in PSE all relate to capital market problems. The problems associated with human capital investments have these implications which are central to the characteristics of an appropriate ICR plan:

1. For tax purposes, PSE investment expenditures must be treated as deductions from income earned as a result of the investment. 
2. The capital market for intangible human capital must be securitised.

3. Operation of an ICR requires a mechanism which allows lenders truthful information about the income of the borrower.

These characteristics are embedded in the proposal for a Private ICR Plan (PP) as outlined below. The PP differs fundamentally from other ICR proposals in clearly delineating the roles of the public and private sector which we detail in the next section.

\section{Structure of the plan}

Under a PP, financial institutions would provide the loans and their administration on an individualized basis. The government would guarantee the loans and register them with the tax authority to ensure compliance (as is the case with many public sector ICR proposals).

The loan program would be based on the following elements:

1. Coverage of the full cost of tuition and a fixed amount for living expenses.

2. PSE institution be permitted to set differentiated fees. ${ }^{2}$

3. The financing of all loans through normal commercial channels and eligibility based solely on attendance at a PSE institution.

4. An insurance component (provided by the public sector) to cover the costs of loan defaults and thus ensure a low interest rate on student loans. An insurance component on the loans to cover death and disability which is the responsibility of the student.

5. Repayment of loan geared to future incomes.

6. Treatment of the loan (including all accrued interest and other financing charges) as an investment in (human) capital for the purposes of income tax.

7. Provision to fall back on the income tax system to aid in collection of the loan if necessary.

A number of arguments can be made in support of full cost of tuition schemes (Stager, 1989). Since the private benefits of PSE significantly exceed the private costs, it may be more equitable for the major beneficiaries 
to bear a greater share of the costs. Others have noted that PSE primarily benefits the middle class while it is paid for primarily from public funds. The economic rationale for full cost fees is that the private benefits exceed the private costs even when full costs are considered.

A central requirement of the $\mathrm{PP}$ is that human capital be recognized as capital in a meaningful way. As with investments in tangible capital, investment in human capital is a cost of earning income and is thus viewed as an appropriate deduction from that income for tax purposes.

While the PP has similarities to other proposed ICR plans, details are important (Kesselman, 1993). We shall therefore discuss some details of the proposed PP in depth.

\section{Details}

Eligibility. Any student accepted into an accredited institution would be eligible for tuition loans covering all tuition costs (these might include course materials such as texts and laboratory items). Educational institutions have entrance criteria which serve, among other things, to decrease the probability that selected students will waste time and money. Should some institutions specialize in "marginal" cases or grant questionable qualifications, the accreditation of the institution might be questioned. ${ }^{3}$

Limits could be imposed on the period of financing, for example, six years of undergraduate degree funding and three years graduate funding. We would argue against such restrictions since they could result in a bias against those who pursue degrees on a part-time basis or they might limit upgrading or changing of fields at some later point in the graduate's career. Indeed the very competitiveness of the world economy implies constant skill upgrading (Economic Council of Canada, 1992).

An essential feature of the loan scheme is that students remain responsible for loan repayment even though repayments may be zero for some periods for which individuals may be out of the work force. The only escape is perpetual non-unemployment! This provides a strong disincentive to wasteful behaviour.

Financial accounting. The PP loans would be arranged though a private financial institution chosen by the applicant. ${ }^{4}$ The student would also be responsible for death and disability insurance on the loan as is common with many consumer and mortgage loans. The financial institution would be responsible for registering the loan with the appropriate government 
agency as well as for the normal accounting and administrative procedures applicable to private loans. The registration would allow the public sector to fulfill specific roles in the case of default of payments.

Since all loans would be guaranteed, the rate of interest to be charged should be a rate close to that given to the institution's most trustworthy customers, typically at (or very near) the prime rate. The administration costs of educational loans may be less than other types of loans since limited financial checks are required in the issuance of educational loans.

Except for those that are in default and which require government intervention, loans can be treated by both the graduate and the financial institution as any private loan. The sole difference lies in the calculation of the annual (monthly) payments. The lender would require an estimate of the gross annual income of the graduate to calculate the minimum (or maximum) required monthly payment. Any payments over the minimum could be appropriately applied to the principal of the outstanding loan.

Defaults. Under the PP, both the government and the financial institution have a role in the collection of debts. The financial institution undertakes all functions associated with the loan, save the legal action or placement with a collection agency. Should such actions be deemed necessary, the institution would first be required to report the details of the delinquent payments to the appropriate government agency. The government agency would have three roles in the event of delinquency: to verify the relevant information (address, employer and income of the graduate from current tax records); to decide upon action to be taken; and to inform the financial institution as appropriate.

There is a wide range of potential actions in the event of payment delinquency. For example:

No action - defaults on loan payment may be income related. Sickness, child bearing and temporary bouts of unemployment would not alone be cause for action. Indeed, in these cases, no special report would be required from the lender and interest would continue to accrue. In cases where the lender does not know the location or status of the graduate, the government could provide the graduate's address and send a letter to the graduate indicating that a meeting with the financial institution is expected. 
Direct intervention - financial counselling by the lending institution or a note on the credit file of the borrower might be sufficient to reestablish loan payments. In extreme cases, the government might consider action to garnishee an appropriate amount from earned income.

Establish a lien - while deduction at source is a last resort for domestic loan holders, it cannot be used on non-Canadian incomes. For graduates living in foreign countries, the financial institution, at the request of the government agency, could be permitted to establish a lien on any Canadian property of the graduate. Other possible actions include refusal to renew passports as suggested by Kesselman (1993).

Allowing some role for the public sector in loan collection does not preclude directives to the financial institutions that all legal means of collection must be attempted. Rather, such a role provides a degree of flexibility which may be of value in overcoming the short run financial problems related to unforeseen expenditures or poor financial management on the part of graduates.

Loan repayments. Students would receive loans to cover tuition, living expenses and course materials during each term of attendance at a PSE institution. These loans would accumulate interest on a normal commercial basis with repayment normally beginning some time after graduation. The first year of repayment would occur when the graduate earns a sufficient amount (based on total income) to qualify for payments and the maximum duration of repayment could extend for, say, thirty years.

The maximum annual repayment required would be equal to $35 \%$ of the difference between after tax expected income (which includes the tax deductibility of the payments) and after tax minimum wage income. (We label this as the "the $35 \%$ rule". $)^{5}$ At lower incomes, payments might not cover the interest costs and thus the accrued amount owing would increase. Over time, as income increases, payments would be expected to cover both interest and principal. In the majority of cases, income would be sufficiently high to repay the loan in less than 30 years. Payments less than $35 \%$ would be permissible subject to the condition that the payment amount be sufficient to discharge the loan completely within 30 years. Finally, there would be no maximum allowable repayment schedule. That 
is, graduates wishing to repay their loans on some accelerated schedule would be free to do so.

The total costs of an eight month academic year at an Ontario University were approximately $\$ 7,665$ in $1989 / 90$ with tuition fees accounting for about $\$ 1,300.6$ Living expenses are a serious income related impediment to access for many students. The argument in favour of loan eligibility for living expenses is that they constitute "set up" or installation costs of the human capital. Eligibility under the current loan programs is based on the financial status of a third party (normally the parents of the student) or the age of the student. These are intended to respond to a perceived need and the view that the public should not pay for those who can afford to pay themselves. Under a PP, living expenses are a (tax deductible) part of the capital investment, which is to be repaid in full.

Although the general living costs would differ somewhat among institutions, we allow $\$ 5,500$ per year for these expenses in 1990 and use a CPI adjustment to obtain the costs in previous years. In principal, PP loans could be based upon the fees for residency with meals at the university attended together with due allowance for books, transportation, and miscellaneous expenses.

\section{Feasibility}

Structure of the PP. The appropriate university budget for analysing the full fee structure for students is generally considered to be the operating budget. Operating budgets are typically about $68 \%$ of the total university budgets in Ontario. ${ }^{7}$ Not included in these operating budgets are the costs associated with lectures, courses and other activities for which academic credits for degrees are not granted, the costs associated with ancillary enterprises which typically run on a fee-for-service basis and any costs associated with sponsored research and trust and endowment expenditures.

Full fees, in principle, should be the marginal cost of an additional student in a particular programme. In practice, full fees are based on the average variable costs of the university's teaching function (which includes salaries and wages and hence some direct research costs). The operating budget is taken to be total variable cost. Full fees have been estimated by the Ontario Ministry of Colleges and Universities and are reported in Stager (1989; Table 3.2, p. 32) for five degree groups. Table 1 shows those fees and also our allocation of the various degree types in the Survey of 1990 Graduates to the five broader categories. 
Table 1

Degree Groups and Full-Cost Fees, 1988-89

\begin{tabular}{|c|c|c|c|}
\hline $\begin{array}{l}\text { Degree } \\
\text { Group }\end{array}$ & $\begin{array}{l}\text { Allocation } \\
\text { by Stager }\end{array}$ & $\begin{array}{l}\text { Allocation of } \\
\text { Survey Graduates }\end{array}$ & $\begin{array}{c}\text { Annual } \\
\text { Tuition }(\$)\end{array}$ \\
\hline 1 & $\begin{array}{l}\text { General Arts \& Science } \\
\text { Journalism }\end{array}$ & $\begin{array}{l}\text { Not Specified } \\
\text { Unknown }\end{array}$ & 5,277 \\
\hline 2 & $\begin{array}{l}\text { Honours Arts } \\
\text { Rehab Medicine } \\
\text { Library Science } \\
\text { Phys. Ed. } \\
\text { Fine Arts } \\
\text { Commerce, Business } \\
\text { Law }\end{array}$ & $\begin{array}{l}\text { Fine Arts, Humanities } \\
\text { Commerce, Law, Economics } \\
\text { Other Social Sciences }\end{array}$ & 7,210 \\
\hline 3 & $\begin{array}{l}\text { Honours Science } \\
\text { Forestry, Music } \\
\text { Pharmacy, Agriculture } \\
\text { Education, Nursing }\end{array}$ & $\begin{array}{l}\text { Agricultural Sciences } \\
\text { Biological Sciences } \\
\text { Mathematics } \\
\text { Physical Sciences } \\
\text { Education }\end{array}$ & 9,143 \\
\hline 4 & $\begin{array}{l}\text { Engineering } \\
\text { Architecture } \\
\text { Optometry }\end{array}$ & Engineering & 9,263 \\
\hline 5 & Medicine \& Dentistry & $\begin{array}{l}\text { Medical and Health } \\
\text { Professions }\end{array}$ & 21,124 \\
\hline
\end{tabular}

Source: Stager (1989), Table 3.2, p. 32 
These full tuition fees are open to discussion. In particular, a number of items in the operating budget are intended primarily to satisfy a perceived social need other than direct research or instruction for degree or certificate credits. In addition, the extent to which tuition fees ought to finance faculty research is an open and potentially contentious issue. While basic research is generally considered to be a public good implying funding from the public sector, it also contributes to the quality of instruction. Such issues are beyond the scope of this study, but their analysis might well reduce the measure of full fees used here. The figures in Table 1 (1989-90 dollars) are adjusted by the CPI to obtain fees in earlier years and for 1990-91. These are considered to be upper bounds on the actual full fees. ${ }^{8}$

Students are assumed to borrow the value of full tuition fees and living expenses for each year of their program. A further $1 \%$ of these costs is added to represent the cost of life and disability insurance on the loans. The loans accrue interest throughout the program at the prime rate of interest. An additional two years of interest compounding is allowed to occur after graduation so as to be comparable to the earnings reported in the Survey of 1990 Graduates. (Under the PP, loan repayments would begin when the graduate earns sufficient income.) The current values of the ICR loans of each degree type as of 1992 for 1990 graduates are reported in Table 2.

In the base case, the flow of maximum required payments is premised on the $35 \%$ rule and a 30 year payment horizon. Under this payment rule, graduates begin payments when their after tax incomes are greater than the after tax earnings of a full time minimum wage earner. ${ }^{9}$ The minimum wage is assumed to grow at a real rate of $1 \%$ per year. Both tuition and living expense loans are treated as investments in human capital for tax purposes. ${ }^{10}$

Income projections are crucial to the analysis of the loan plan but predictions of this sort are fraught with problems. We approach the issue from two directions. The first approach uses the incomes reported by graduates in the Statistics Canada Survey of 1990 Graduates and makes assumptions on the growth paths of those incomes. The second approach uses the earned income deciles by age (ages 24 to 53) from the 1986 Census reported by Stager and Derkach (1992). While both approaches use real earned incomes for all calculations, the PP would use total incomes for repayment calculations. 
Table 2

Loan Principals of 1990 Graduates in 1992

\begin{tabular}{ccc}
\hline Degree Group & $\begin{array}{c}\text { Duration of } \\
\text { Degree (yrs) }\end{array}$ & $\begin{array}{c}\text { Accrued Loan } \\
(\$-1992)\end{array}$ \\
\hline 1 & 3 & 42,462 \\
& 4 & 58,271 \\
2 & 5 & 75,033 \\
& 3 & 50,272 \\
& 4 & 68,991 \\
3 & 5 & 88,833 \\
& 3 & 58,083 \\
& 4 & 79,712 \\
4 & 5 & 102,634 \\
& & \\
& 3 & 58,567 \\
& 4 & 80,377 \\
\hline Average & 5 & 105,918 \\
\hline
\end{tabular}

Source: Table 1 and calculations by authors

Notes:

1. Tuition (1988-89, Table 1) and living expenses $(\$ 5,500$ in 1989-90) are CPI adjusted for the years 1985-90. Loans include a further $1 \%$ for insurance and are compounded annually at the then existing prime rate (annual averages) until 1992.

2. The Survey does not differentiate between Medical Degrees and Health Science Degrees. Graduates in this group are assumed to experience the same aggregate default rate as other groups combined.

3. The average loan value weights each type of loan by the respective number of graduates. 
The Survey of 1990 Graduates asked graduates to report their last week's earnings and the annual earnings if that jobs had continued for one year. Thus the part-time or temporary nature of that job is included in the reported annual earnings. Respondents reporting earnings of less than $\$ 25,000$ were placed in income classes of: $[<\$ 15,000]$; $[\$ 15,000-$ $\$ 17,000] ; \ldots ;[\$ 23,000-\$ 25,000]$. Incomes assigned to individuals in these classes were the class midpoints and $\$ 15,000$ for those reporting less than this figure. Those reporting themselves as unemployed, and hence not reporting any earnings at the time of the survey, are assumed to be able to find employment, given the low unemployment rates for graduates (Report of the Advisory Council on Adjustment, 1989, p 30), starting at $\$ 15,000$. The lower bound of $\$ 15,000$ is approximately $\$ 2,000$ higher than full time minimum wages earners would receive annually. Those who were employed but did not report earnings and those who were in the Health and Medical Profession degrees were assumed to have the same default rate as the aggregate of employed (reporting earnings) and unemployed together."

Gender-based earnings differentials are very small in the Survey but it is the female participation rate which complicates the earnings projections. The female participation rate is approaching that of males for the university educated. The participation rate for university-educated females aged between 25-44 was 88\% in 1994 (Butlin, 1995). "In 1994, $77 \%$ of female university graduates versus $82 \%$ of male graduates were in the paid workforce" (Statistics Canada, 1995). The most recent generation has a participation rate much higher than their predecessor. Should this continue, the gap in participation rates between the sexes may be eliminated. (The type of participation as between part-time and full-time work, however, may continue to differ.) To capture the possible effects of family formation on earnings paths we assume relatively flat earnings growth rates in the first number of years after graduation. Real earnings are assumed to grow at $7 \%$ per year for the first four years, at $5.5 \%$ for the next four years, at $3.5 \%$ for the next 12 years and $1.5 \%$ thereafter. The respective 1990 growth rates of mean earnings for Arts and Science male graduates are calculated to be $9.5 \%, 8.6 \%, 3.5 \%$ and $1.2 \%$ (Stager $\&$ Derkach, 1992, p. 36). The smaller assumed growth rates in the earlier periods are attached to both male and female incomes and thus reflect an implicit assumption of a more equal sharing of participation effects of family formation. 
Figure 1 shows the relationship between the lowest earnings profiles (earnings starting at $\$ 15,000, \$ 16,000$, and $\$ 18,000$ ) and the mean male high school earnings profile. One effect of the earnings and growth assumptions is that $25 \%$ of the sample would have a present value of earnings less than that of a male high school graduate.

Default rates (the value of loans not repaid expressed as a proportion of total loan value) and dollar values of default are calculated for real interest rates of $4.5 \%, 6 \%$ and $7.5 \%$ with repayment periods of either 25 or 30 years. The results for this approach to income projections are reported in Table $3 \mathrm{a}$. The default cost of establishing the capital market for students loans would be approximately $\$ 500$ million at current real interest rates of about $5 \%$. The dollar value of default is about $7 \%$ of the total value of loans.

The second approach ( the Census approach) to earnings projections is to use census data on earnings by age. The data used in this study are taken from Stager and Derkach (1992, Tables A9 \& A10, hereafter the S\&D tables). Earnings for Ontario residents from the 1986 Census were adjusted to reflect 1990 earnings by Stager and Derkach and have been further adjusted to 1992 earnings for this study. ${ }^{12}$ These tables give, respectively, the male and female median employment incomes, by deciles, for Arts and Science graduates from ages 21 through 58. Earnings data for those aged between 24 and 53 are used for the 30 year repayment calculations that follow. The data take into account those persons who did not work and thus incorporate participation rates that existed in 1986.

The use of cross-sectional data to estimate lifetime income tends to under-estimate individuals' true lifetime incomes. Those who experience periodic unemployment because of further study, illness, family responsibilities or job shifting, and those whose income is only partially in the form of wages and salaries would rank in the lower deciles of earned income for only a small part of their working lives. One solution to this problem is to adjust the rate of growth of earnings. ${ }^{13} \mathrm{~A}$ second, and more serious problem in the present context, is that the participation rate for female graduates has grown since 1986 and this will have considerable effect over the 30 age cohorts to be brought into a newly started PP. Thus the tables used for female earnings, representing participation choices and earnings of 30 previous graduating cohorts are likely to seriously under-estimate earnings paths for the 1990 graduating cohort in their 30 year repayment period. 


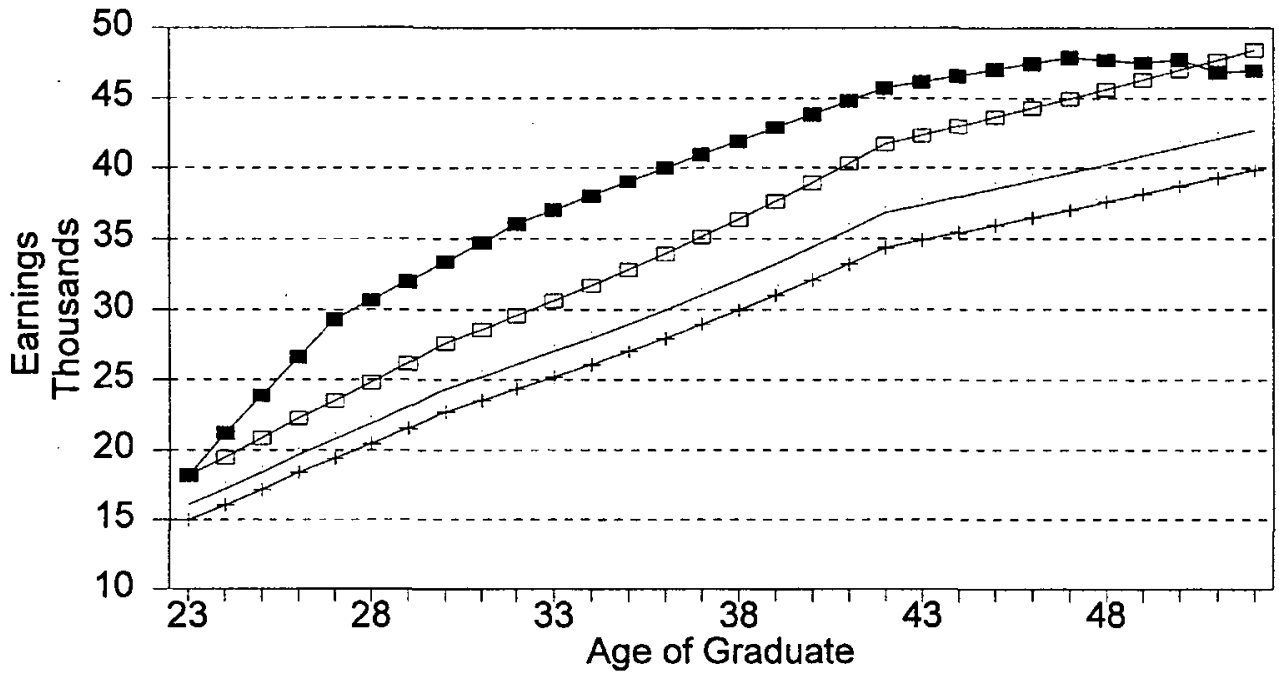

\section{$\rightarrow$ Mean High School —_ Start at $\$ 15,000 \_$Start at $\$ 16000 \_$- Start at $\$ 18,000$}

\section{Figure 1 \\ Low Earnings Profiles}

Mean male high school earnings are taken from Stager and Derkach (1992, Table A3) and adjusted to 1992. Earnings profiles for the Survey approach have initial earnings grow at $7.0 \%$ for four years, $5.5 \%$ for four years, $3.5 \%$ for ten years, and $1.5 \%$ for the remaining eleven years. 
Table 3a

\section{Default Summary by Survey Approach}

\begin{tabular}{|c|c|c|c|c|}
\hline $\begin{array}{c}\text { Repayment } \\
\text { Period }\end{array}$ & $\begin{array}{l}\text { Real Rate } \\
\text { of Interest }\end{array}$ & $\begin{array}{l}\text { Graduate } \\
\text { Group }\end{array}$ & $\begin{array}{c}\text { Default in } \\
\text { Billions \$-1992 }\end{array}$ & $\begin{array}{l}\text { Default } \\
\text { Rate \% }\end{array}$ \\
\hline \multirow[t]{12}{*}{25 years } & \multirow[t]{4}{*}{$7.5 \%$} & Employed & 0.46 & 9.54 \\
\hline & & Unemployed & 0.37 & 59.68 \\
\hline & & Omitted & 0.24 & 15.38 \\
\hline & & Aggregate & 1.08 & 15.38 \\
\hline & \multirow[t]{4}{*}{$6.0 \%$} & Employed & 0.34 & 7.05 \\
\hline & & Unemployed & 0.32 & 52.04 \\
\hline & & Omitted & 0.19 & 12.17 \\
\hline & & Aggregate & 0.85 & 12.17 \\
\hline & \multirow[t]{4}{*}{$4.5 \%$} & Employed & 0.22 & 4.47 \\
\hline & & Unemployed & 0.26 & 41.31 \\
\hline & & Omitted & 0.14 & 8.66 \\
\hline & & Aggregate & 0.61 & 8.66 \\
\hline \multirow[t]{12}{*}{30 years } & \multirow[t]{4}{*}{$7.5 \%$} & Employed & 0.38 & 7.85 \\
\hline & & Unemployed & 0.34 & 54.82 \\
\hline & & Omitted & 0.21 & 13.16 \\
\hline & & Aggregate & 0.92 & 13.16 \\
\hline & \multirow[t]{4}{*}{$6.0 \%$} & Employed & 0.22 & 4.47 \\
\hline & & Unemployed & 0.26 & 41.31 \\
\hline & & Omitted & 0.14 & 8.66 \\
\hline & & Aggregate & 0.61 & 8.66 \\
\hline & \multirow[t]{4}{*}{$4.5 \%$} & Employed & 0.12 & 2.54 \\
\hline & & Unemployed & 0.18 & 29.44 \\
\hline & & Omitted & 0.09 & 5.59 \\
\hline & & Aggregate & 0.39 & 5.59 \\
\hline
\end{tabular}

Notes: 1. Earnings paths of graduates are constructed from reported earnings in 1992 from the Survey of 1990 Graduates. Earnings start at $\$ 15,000$ (for those reporting less than $\$ 15,000$ ), at $\$ 16,000$ (reported earnings $\$ 15,000-\$ 17,000$ ), at $\$ 18,000, \$ 20,000$, $\$ 22,000$, and $\$ 24,000$ respectively for subsequent $\$ 2,000$ ranges. Earnings are then assumed to grow at $7 \%$ per year for four years, $5.5 \%$ for the next four years, $3.5 \%$ for the next 12 years, and $1.5 \%$ thereafter. Default is calculated as the difference between the present value of potential repayments of the earnings streams and the cost of the degree by type and duration for each graduate.

2, The Employed were graduates who reported employment and earnings. The Unemployed were assigned initial earnings of $\$ 15,000$. The Omitted group includes those reporting no earnings and the Medical and Health Degree graduates which are assigned the average default rate of the other two groups. 
Table $3 b$

\section{Default Summary by Census Approach}

Repayment Period of 30 years

\begin{tabular}{|c|c|c|c|c|}
\hline \multicolumn{5}{|c|}{ Default Rate in \% } \\
\hline $\begin{array}{c}\text { Real Rate } \\
\text { of Interest }\end{array}$ & $\begin{array}{c}\text { Males } \\
\text { (S\&D) }\end{array}$ & $\begin{array}{c}\text { Females } \\
\text { (S\&D) }\end{array}$ & (1.7 births) & (1.2 births) \\
\hline \multirow{2}{*}{$4.5 \%$} & 15.45 & 44.14 & 18.05 & 16.18 \\
$6.0 \%$ & 16.57 & 45.21 & 21.16 & 19.31 \\
$7.5 \%$ & 19.53 & 48.17 & 25.51 & 23.24 \\
\cline { 3 - 5 } & & \multicolumn{3}{|c|}{ Combined Average Default Rate } \\
\cline { 3 - 5 } & & (S\&D) & $(1.7$ births) & $(1.2$ births $)$ \\
\hline \multirow{2}{*}{$4.5 \%$} & & 31.51 & 16.91 & 15.86 \\
$6.0 \%$ & & 32.61 & 19.14 & 18.11 \\
$7.5 \%$ & & 35.57 & 22.88 & 21.61 \\
\hline
\end{tabular}

Notes: 1. S\&D, Stager and Derkach (1992) Tables A9 and A10 report Ontario male and female graduates' earnings in $\$ 1990$ by age 21 to 58 years old in deciles. These earnings are increased by $9.7 \%$ to reflect projected 1992 earnings (Canism D747018, noncola, all industry wage increases). Each earnings decile (age 24 to 53 years) is treated as an earnings path from which the present value of potential repayments is calculated.

2 , Simulated earnings paths for females use the male deciles as default paths and an average of 1.7 or 1.2 births per female. A birth implies three years out of the labour force and no earnings. Probabilities of births are ad hoc and are given by the following schedule:

\begin{tabular}{|lccccccccccccccccccccc|}
\hline Age: & 24 & 25 & 26 & 27 & 28 & 29 & 30 & 31 & 32 & 33 & 34 & 35 & 36 & 37 & 38 & 39 & 40 & 41 & 42 & 43 & 44 \\
1.2 births & 6 & 6 & 7 & 7 & 8 & 10 & 10 & 10 & 10 & 9 & 8 & 7 & 6 & 5 & 4 & 3 & 2 & 1 & & & \\
1.7 births & 8 & 8 & 9 & 10 & 10 & 12 & 12 & 11 & 11 & 11 & 10 & 10 & 10 & 10 & 7 & 6 & 5 & 4 & 3 & 2 & 1 \\
\hline
\end{tabular}

3. The default rate is calculated for each male and female earnings decile given an average degree cost of $\$ 66,128$. The default rates for all male and all females is the average over all deciles for that group.

4. The combined average default rate uses the 1990 proportions of .44 and .56 for males and females respectively. (Education in Canada, 1992-1993, Table 37) 
The changing female participation rate and its potential effects on earnings are addressed as follows. In addition to examining the earnings decile data for females we simulate earnings flows for females which are based upon the decile data for males. Our approach is to attribute lower participation rates to females as a result of childbirth. The fertility rate for Canada was 1.52 in 1987, rose to 1.7 in 1990, and remained at that figure through 1993 (Statistics Canada, 1995b, p. 7). While there is some evidence of countercyclical movements in fertility rates (Hyatt \& Milne, 1991), other studies suggest that participation rates for females is likely to continue to decrease. ${ }^{14}$ We construct earnings paths based upon 1.7 and 1.2 births per female. The characteristics of female university graduates, education, age when first child is born, and earnings, are those associated with lower fertility rates. ${ }^{15}$

Earnings paths are constructed assuming that, in the absence of children the female age-earnings decile table would replicate the S\&D male age-earnings decile table. Thus each male decile earnings path is treated as the earnings path for females who have no children. In each year, women between the age of 24 and 41 have a given probability of having a child such that the average number of children over the period is 1.2 or 1.7. (The probabilities are adhoc and are reported in Table 3b.) A birth is assumed to result in three years out of the labour force. ${ }^{16}$ When the fertility rate is 1.2 and the period out of the labour force is three years, the participation rate is approximately $10 \%$ less than that of males over the 30 year repayment period. Earnings on re-joining the labour force is at the rate which was earned in the last full year of work.

Since the decile data are not matched to degree groups, we use a weighted average (by course type, duration, and number of graduates) of the cost of a degree from the Survey. After interest compounding and insurance this cost was $\$ 65,473$ in $\$ 1992$. The simulations generate earnings flows and repayment capacities for females under the $35 \% / 30$ year repayment rule. The repayment capacities are sorted by size and the median value of each decile is taken to represent the repayment made for that decile. The default rate for each decile is one minus the repayment capacity to cost ratio. The aggregate default rate sums the default rates over each of the deciles and is calculated for both males and females. Default rates for the Census approach are reported in Table 3b.

Default rates and repayment burdens. The default rates are based upon all students borrowing the maximum eligible amount. The calculated 
default rates are used to calculate the dollar values of default. The total cost to the public sector includes the forgone tax revenues (tax expenditure) due to the deductibility provisions of loan repayments. ${ }^{17}$ This tax allowance is found to be approximately $35 \%$ of the value of loans which are repaid. Those with starting incomes above $\$ 30,000$, approximately the median income in the Survey, would repay their loans entirely. From the last column in Table $4 \mathrm{a}$, those with starting incomes of $\$ 30,000$, have an after-tax share between $62 \%$ and $69 \%$ of their loans but have no defaults. The difference between the repayment share and $100 \%$ is the value of the tax deductibility provisions for those with no defaults. Those with higher incomes have been calculated to repay $60 \%$ of loans. Thus the value of the tax deductions for half of the students is higher than $35 \%$ of the loan value. Those with lesser incomes have some value of default and lesser values of tax deductibility.

The approximate relationship between default rates and the total cost to the public of the loan plan are shown in Figure 2. If $d$ is the default rate and TLV is total loan value, then the tax expenditure of the plan is given by $\mathrm{TE}=0.327(1-\mathrm{d}) \mathrm{TLV}$. The total cost of the PP is approximately $\mathrm{TE}+\mathrm{dTLV}$. The federal and provincial shares of the tax expenditure are roughly $65 \%$ and $35 \%$ respectively.

The repayment burden for graduates under the PP is defined as the difference between after-tax earnings calculated with the loan payments and after-tax earnings without the student loan payments expressed as a proportion of gross earnings. For lower income earners, those whose payments are at the maximum required rate throughout the repayment period, the burden is approximately $9 \%$ to $12 \%$. The burdens have been calculated for the lowest earnings paths from the Survey approach and are shown in Figure 3. One can interpret these burdens as the maximum repayment tax rate on gross earnings implied by the repayment scheme.

For graduates who must pay at the maximum rate, the repayment burdens are independent of the size of the loans to be repaid, the interest rate, and the payback period. The burden would increase with decreases in the basic exemption level of earnings (the after-tax minimum wage was an arbitrary choice) or by an increase in the proportion of eligible earnings required for repayment. Changing the $35 \%$ repayment rule by $(+/-) 5 \%$ would change the repayment burdens by approximately $(+/-)$ $1.5 \%$ and the dollar value of default by approximately $(-1+) \$ 0.2$ billion. The higher the repayment burden, the lower will be the default value. $\mathrm{A}$ 


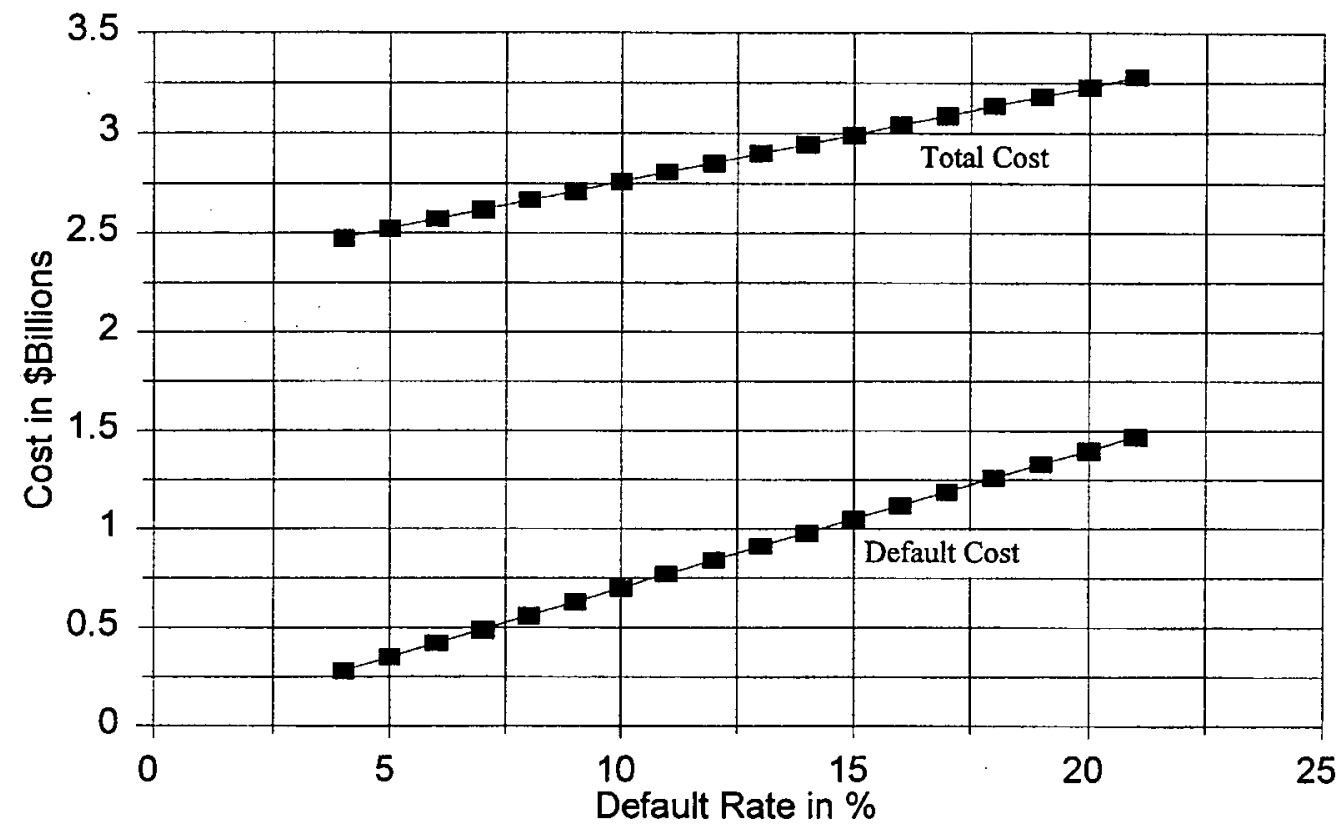

Figure 2

Total Cost of Loan Plan

Total Cost includes the dollar value of default and the income tax deductions to graduates (forgone revenues for the public sector) approximated as $32.7 \%$ of the value of loans repaid. 


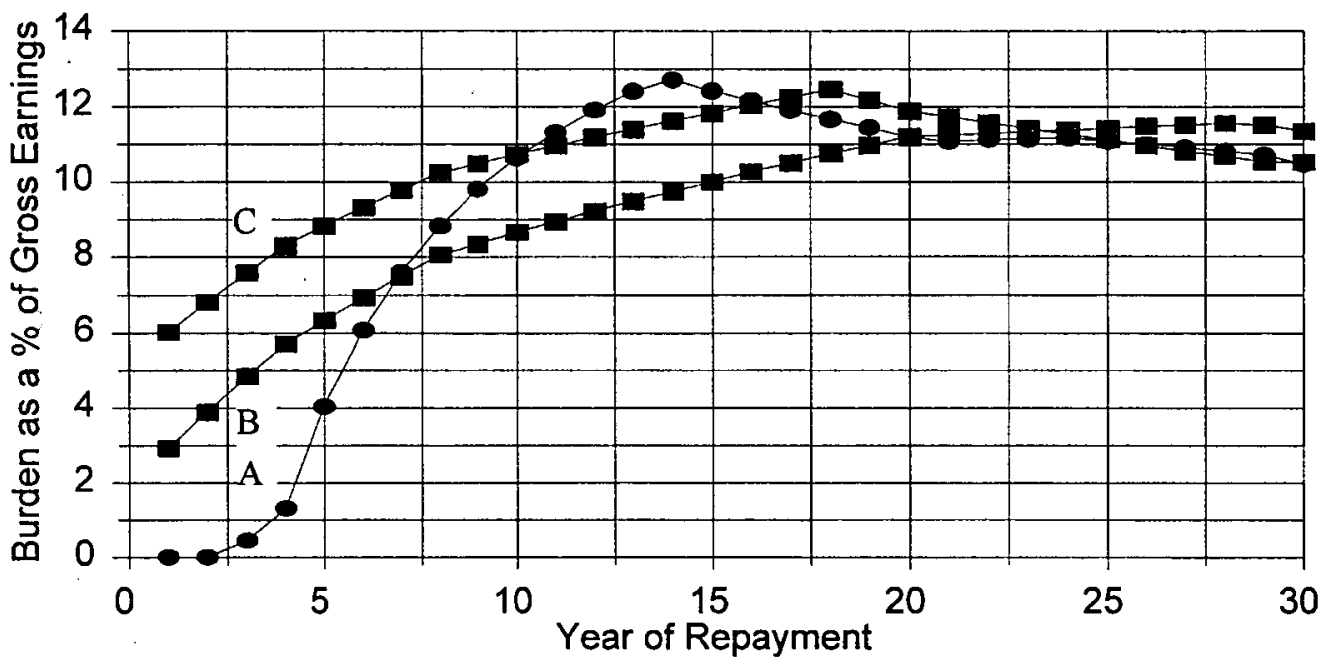

\section{Figure 3}

\section{Burden of Repayment for Graduates}

Burden is defined as the after tax value of repayment as a proportion of gross earnings.

A. Burden based on male graduate earnings in the third decile.

B. Burden based on the Survey approach earnings path with initial earnings of $\$ 15,000$.

C. Burden based on the Survey approach earnings path with initial earnings of $\$ 18,000$. 
$39 \% / 25$ year rule has the same dollar value of default as does the $35 \% / 30$ year rule. There are clearly trade-offs in the design of the repayment structure. The $35 \% / 30$ year structure permits the burden to be less than $10 \%$ per year for half of the repayment period for the lowest income earners and generally less than $12 \%$ per year for others.

The repayment burden on lower income graduates is little affected by a reduction in allowable loans. In particular, if students were not permitted to borrow against living expenses, the calculated cost of default would fall substantially, but the burden to the lowest income group would remain at $9 \%$ to $11.5 \%$ over the last half of the repayment period simply because they would still be repaying at the maximum rate.

Although graduate degree programs have not been analysed, scholarships and employment as teaching or research assistants could reduce considerably the value of additional loans required. Moreover, with starting incomes in excess of $\$ 30,000$, the individual with a graduate degree has the capacity to discharge a loan in excess of $\$ 100,000$. Involuntary defaults from this group can be expected to be small.

Extending the PP to PSE institutions other than universities would seem to be financially feasible. Assuming the income path which starts at $\$ 15,000$ and a real interest rate of $7.5 \%, \$ 34,400$ of student loans could be repaid. This is approximately $80 \%$ of the total costs involved in a three-year general degree program. The majority of non-degree PSE programs are less than three years in length and the incomes of graduates are, on average, greater than the mean of male high school graduates. A direct empirical study of this sector might well suggest a repayment burden of less than $10 \%$.

Student and public sector shares. A different perspective on the costs of the PP can be presented by comparing the shares under three different options: the current arrangement, the current arrangement with the student share of fees increased to $50 \%$, and, the PP. Tables $4 \mathrm{a}$ and $4 \mathrm{~b}$ show both the student shares as well as the public sector share under these three options. Student shares under the current $25 \%$ fee structure or a $50 \%$ fee structure include both the payable fees and living expenses. (Full fees here are as defined in Table 1.) These figures overestimate the student share to the extent that current subsidies and tax expenditures are not included. Unlike the PP, these shares are not income dependent. Shares under the PP are relatively less for lower income graduates due to the default subsidy. Shares for higher income graduates are less than unity because of the tax deductibility provisions 
Table $4 \mathrm{a}$

Student and Public Sector Shares of Total PSE Costs - Student Shares

\begin{tabular}{|c|c|c|c|c|c|c|c|c|}
\hline & \multicolumn{2}{|c|}{\begin{tabular}{|l} 
Current Structure \\
Living costs plus \\
\end{tabular}} & & \multicolumn{4}{|c|}{$\begin{array}{c}\text { After Tax Shares } \\
\text { Survey Approach, Initial Earnings }\end{array}$} \\
\hline Degree & Duration & $25 \% \mathrm{Fee}$ & $50 \% \mathrm{Fee}$ & & $\$ 15,000$ & $\$ 20,000$ & $\$ 25,000$ & $\$ 30,000$ \\
\hline \multirow[t]{3}{*}{ Group 1} & 3 & 0.48 & 0.62 & & 0.58 & 0.72 & 0.75 & 0.69 \\
\hline & 4 & $0.48^{\circ}$ & 0.62 & & 0.43 & $0.70^{\circ}$ & 0.69 & 0.67 \\
\hline & 5 & 0.48 & 0.62 & & 0.33 & 0.53 & 0.66 & 0.66 \\
\hline & & & & & & & & \\
\hline \multirow[t]{3}{*}{ Group 2} & 3 & 0.43 & 0.58 & & 0.43 & 0.70 & 0.71 & 0.69 \\
\hline & 4 & 0.43 & 0.58 & & 0.36 & 0.58 & 0.67 & 0.67 \\
\hline & 5 & 0.43 & 0.58 & & 0.28 & 0.45 & 0.61 & 0.63 \\
\hline & & & & & & & & \\
\hline \multirow[t]{3}{*}{ Group 3} & 3 & 0.38 & 0.54 & & 0.42 & 0.68 & 0.70 & 0.68 \\
\hline & 4 & $0.38^{\circ}$ & 0.54 & & 0.31 & 0.51 & 0.65 & 0.65 \\
\hline & 5 & 0.38 & 0.54 & & 0.24 & 0.39 & 0.53 & 0.62 \\
\hline \multirow{3}{*}{ Group 4} & 3 & 0.38 & 0.54 & & 0.42 & 0.68 & 0.70 & 0.68 \\
\hline & 4 & 0.38 & 0.54 & & 0.31 & 0.50 & 0.66 & 0.65 \\
\hline & 5 & 0.37 & 0.52 & & 0.23 & 0.39 & 0.52 & 0.62 \\
\hline
\end{tabular}

Notes: 1. Total costs include living expenses and tuition. Student shares in the Survey Approach are based on a $7.5 \%$ real interest rate and $35 \%$ - 30 year repayment rule.

2. Student shares under current funding include $25 \%$ or $50 \%$ of full fees but deducts Canada Student Loan subsidies and tax deductions, a total of $\$ 1$ billion (HRDC, 1994, Table 1). Student shares under the PP are calculated on an after tax basis. 
Table $4 b$

\section{Student and Public Sector Shares of Total PSE Costs - Public Sector Shares}

\begin{tabular}{|c|c|c|c|c|c|c|}
\hline Real Rate & Survey & \multicolumn{3}{|c|}{ Census Approach } & \multicolumn{2}{c|}{ Current Funding } \\
\cline { 3 - 6 } of Interest & Approach & S\&D & 1.7 births & 1.2 births & 25\% fees & $50 \%$ fees \\
\hline $4.5 \%$ & 36.5 & 54.1 & 44.1 & 43.4 & 59.8 & 44.7 \\
\hdashline $6.0 \%$ & 38.5 & 54.8 & 45.6 & 44.9 & & \\
\hdashline $7.5 \%$ & 41.6 & 56.8 & 48.1 & 47.3 & & \\
\hline
\end{tabular}

Notes: 1 . The public sector share under current funding includes the student loan subsidies in the Canada Student Loans Program as well as tax benefits mentioned in Table 4a, note 2.

2. Public Sector Share of Total Costs is the sum of the default rate (Table 3b) and the reduction in tax revenues to the public sector from the tax deductability provisions of the PP. This tax loss is approximated by $32.7 \%$ of the proportion of loan repaid which is ( 1 -default rate). The tax loss factor of $32.7 \%$ is based on direct calculation using the Survey Approach with real interest rates of $7.5 \%$.

of the PP. Note in particular, that these shares are not much greater than those for students under the $50 \%$ fee plan.

In calculating the public sector shares, allowance has been made for the subsidies to students under the Canada Student Loans Program (CSLP) as well as tax expenditures which we assume constant (\$1 billion) under both $25 \%$ and $50 \%$ fee structure. The cost to the public sector for the PP includes both the expected value of defaults as well as the tax expenditures with the deductibility provisions.

The public sector shares under the $25 \%$ and $50 \%$ fee structures are $58 \%$ and $43 \%$. Should both male and female income streams be unchanged from Stager and Derkach's income deciles, the public sector share would be $60 \%$ under a PP. This share is reduced to $48 \%$ under the simulation with 1.2 births per female. To the extent that the income paths generated form the Survey of 1990 Graduates provide a useful projection of income paths, the public share of PSE expenditures is $41 \%$. The range of share estimates under the PP is approximately the same as the current funding system with payable fee in the $25 \%$ to $50 \%$ range. Our expectation is that the raw $S \& D$ data represent a considerable understatement of 
the potential income paths of both males and females. The 1.2 births per female approach approximates an $88 \%$ participation rate, but incomes in this approach (based on male decile figures for 1990) can be expected to underestimate the income flows. The Survey-Income approach assumes high and constant participation rates but assigns relatively low incomes to the bottom third of graduates as compensation. We would suggest that a public share of $41 \%$ to $48 \%$ of PSE costs would be a reasonable estimate.

\section{Design Issues}

While the details of the proposed PP have been made explicit, a number of broader issues regarding the conceptual design of the program are implicit. The three major issues discussed in this section are whether an ICR should be self-financing or subsidized as in the PP, the role of the public and private sectors and the extent to which introduction of a PP involves an intergenerational transfer of the burden for financing PSE.

\section{The Self-financing ICR, Equity versus Debt}

If an ICR is to be a self financing loan system, then those earning higher incomes would pay for their own loans as well as the defaults or under-payments incurred by lower income graduates. Subsidization of defaults by the general taxpayer, as in the proposed PP, would be replaced by cross-subsidization among graduates. However, an alternative view of a self-financing ICR is that the public sector makes an equity investment in the students' education (human capital) and that repayments are the dividend payments on the invested equity. In this model, dividend payments are linked to income with higher income graduates naturally generating more dividends. While an interesting application of risk spreading, an important problem in the application to PSE is that the projects (students) over which the public sector investment is made do not produce independent income (dividend) streams. Those with lower dividend payouts relative to their equity cause others to have higher dividend payouts. We presume that dividends repaid would be proportionally related to the loan (equity) amounts but repayments by the "better off" would also pay for the default of others. Large portions of students who perceive themselves as having good income prospects (better averages in the upper years of study or easier access to the job market) or those with greater abilities to self finance, would be expected to minimize their loans and thus minimize the amount of 
dividends to be paid over and above the value of their personal loan. The self selection would reduce the number of potentially high dividend graduates, increase the burden on those remaining and have negative consequences for equality of access.

The obvious solution to this problem would be to require all students to partake of the ICR; that is, there could be no opting out. ${ }^{18}$ Such an ICR would then be very much like the private loan market with "dividend rates" equivalent to risk adjusted market rates. That an extensive private market does not exist for student loans is consistent with the requirement that a self-financing ICR be coercive in requiring the participation of all students. A self-financing ICR for all PSE students does not involve a public sector solution to the uncertainty problem. Rather it forces a private sector solution on to unwilling participants.

Under the PP, the default subsidy is the cost of creating the conditions necessary for the emergence of a capital market. The benefits of this market include the increase in accessibility to PSE, particularly to those students in poorer financial circumstances. Canada currently "provides nearly $\$ 1$ billion in [education] aid each year" through the Canada Student Loans Program alone. ${ }^{19}$ This is the current amount that the federal government is willing to allocate to enhance financial accessibility. The cost of the defaults under the PP from Table $3 \mathrm{a}$ is approximately this amount, but it purchases a mechanism which has the potential to eliminate financial accessibility problems.

\section{The Public Sector Role}

An ICR typically defines at least two roles for the public sector, a collection role and a financing role. The financing role has been discussed above. The collection role includes, at a minimum, the requirement that the public sector be able to follow the graduate through tax records. Indeed, the argument that the public sector use the tax system for collection purposes is premised on objectives of simplicity and efficiency.

Ideally, the repayment rule would be very simple, for example, repay $\mathrm{x} \%$ of income. Collection through the tax system would be simple only to the extent that repayment followed the simple rule. The fundamental objective of an ICR is repayment flexibility based on income. Collection by tax authorities implies that account balances be kept for all students. This is neither trivial nor costless. It requires construction and maintenance of a large scale database which would be peripherally related to 
the functions of the tax authorities rather than an integral part of the existing tax accounting mechanisms.

Over time, changes in fee structures, enrollments and interest rates can be expected to occur which may require changes in the simple repayment rules. Either tax rates must change for everyone or for particular sets of individuals. The former case implies intergenerational crosssubsidization as well as a unilateral (government sponsored) change to payments not foreseen as part of the arrangement. In the latter case, the tax mechanism becomes a considerably more complicated vehicle. ${ }^{20}$

The tax system is not well suited to treat like incomes differently. A given income stream could repay a given loan in fifteen years, and a graduate with this income would not be able to extend payments over twenty-five years or to reduce the period to ten years. The term structure of the loans is essentially out of the graduates' control. Allowing for repayment flexibility, payments above the rule and payments below the rule, requires the maintenance of financial records for each individual on an ongoing basis.

The variety of loans, income flows, temporary default of payments, PSE programs, and changes over time argue for a flexible ICR plan. The infrastructure required to handle such problems on an individual basis already exists in the Canadian Financial Sector and has a well known cost structure, market interest rates.

The public sector plays an important informational role in that it must be able to forward income related and location information to the private sector institutions. Current private sector collection of student loans is made difficult primarily because graduates experience short term financial difficulties or because graduates do not inform the collecting institution of their location. To a large extent, many of these problems can be alleviated under the PP by simple information flows from the public to private sector.

\section{Intergenerational Transfer of the Burden}

There are a number of complications that arise in assessing the intergenerational transfer of the PSE burden to graduates under the PP. The burden transferred to the new generation is considerably less on a per graduate basis than that incurred by a new generation graduate financed under the PP for two reasons. First, all non PSE beneficiaries subsidize the PSE users in the current scheme; and second, the public sector portion 
of PSE covers only a portion of fees and living expenses. Previous generations have paid for much of their total costs while they were students.

One view of an intergenerationally fair transition would be that current generation taxpayers continue to pay for the PSE expenditures made to date and new graduates pay only their own expenditures. Total PSE expenditures are approximately $\$ 16$ billion and total incomes (wages, salaries, supplemental income, and corporate income before taxes) are about $\$ 424$ billion. The average aggregate tax rate for PSE is thus about $3.77 \%$ of direct gross income revenues (1992 figures). Thus if the current generation of taxpayers were to continue paying this average $3.77 \%$ tax, they would reduce the average rate to $0 \%$ over 30 years and repay the current scheme obligations. All taxpayers, not just new PP graduates share in the burden transferred. ${ }^{21}$

\section{Incentives}

Distinct from access and financing, the usual argument for an ICR system together with a differentiated fee system has been to give incentives to both students and institutions to be cost and quality conscious. These incentives will be specific to the details of any ICR and warrant attention.

Most PSE graduates are clearly worse off in a move to the PP, as they are under increasing fees with the current financing system. The increase in the (real or perceived) price to students moving to the PP might be expected to reduce demand for PSE. The optimal quantity of PSE will be purchased when the expected risk adjusted rate of return on the investment is equal to prevailing market rates. To the extent that PSE investment has higher than normal returns, pure economic rent is earned. With no barriers to access, rent seeking would tend to increase PSE investment. Access to investment financing is guaranteed at relatively low rates and defaults are not borne directly by the investor. PSE thus remains a lucrative investment opportunity. While students may be justified in decrying higher real costs under the PP, investment in PSE would still be the best long term financial opportunity for most. Moreover, accessibility need not be constrained by financial considerations and those not formerly able even to contemplate PSE could enter the arena.

Particular PSE programs with expected returns less than the market return would be expected to contract. If subsidization is considered, the preferred public sector choice may be the subsidization of measures aimed at improving such things as quality and delivery of PSE services 
as a means to improving the incomes of graduates through, for example, equipment or capital purchases, re-engineering of courses or curricula, or research sponsorship. The alternative, fee subsidization, reduces the cost of investment to the student rather than increasing the income prospects and involves, typically, a more permanent commitment by the public sector and engenders a less efficient use of resources.

Under current PSE funding, many students have strong incentives to undertake part-time work, to work full-time before undertaking PSE, or to interrupt full-time study with full-time work. Families also make sacrifices to help with PSE financing. While the necessity of work and family financing is reduced considerably with the PP, traditional methods of finance remain as options for reducing the loans which would otherwise be required.

The incentive effects on family formation, and in particular female choices regarding work force participation, may be undesirable. The central issue is not the potential value of loan defaults for this group, but rather the increased burden of repayment directly attributable to family responsibilities. Interest compounding continues and the outstanding principal increases while the individual is out of the labour force. The increased burden and the incentives to reduce or retard family formation may be considered as socially undesirable and public sector intervention may be warranted. Such an intervention might take the form of interest forgiveness for either of the parents for some period, say three years per child. While this is a rather blunt instrument, it is simple and allows the parents to choose, if applicable, which loan to modify. Moreover, it is not dependent upon the work force participation of either parent.

There has been concern that the incentive mechanism under ICR's in general would encourage programs to be more closely focused on the labour market. The PP is clearly a market oriented mechanism. That all university degrees do not lead to directly related jobs has always been the case. The PP gives incentives to Universities to establish links with Community Colleges or other PSE institutions in order to provide pertinent information and possibly courses outside of the degree program. There may be no particular need to change the content of a general Arts or Science program. But such programs may have a competitive advantage in attracting students by making available access to more practical and labour market oriented courses. The PP would allow students to take academic courses and labour market relevant courses. 
The incentives for PSE institutions and students are broader than the cost/quality discussion typically implies since both players must be concerned about future employment and educational opportunities. The Economic Council of Canada (1992) stressed the importance of the "Learning Continuum", the relationships among educational institutions and the need for periodic upgrading. It concludes that there is a "lack of clear pathways, linkages, and accreditation between these various elements of the continuum" (p. 17). The concern over employment and labour force evolution, together with competition for students, may constitute the required incentives to coordinate and collaborate among the different types of PSE institutions. Such incentives are consistent with a "coherent learning system" so strongly advocated by the Council.

\section{Summary}

It would seem to be highly probable that some form of an ICR, or perhaps multiple plans will be introduced together with higher fees for students undertaking PSE. A particular form of an ICR has been designed and analysed. The proposal is based on treating the investment in human capital equivalently to an investment in physical capital for tax purposes. To allow the functioning of the private markets in the financing of PSE, the public sector must guarantee the loans and provide an information service to the private sector. This proposal encompasses loans covering full tuition fees and living expenses and repayments geared to income and thus increases accessibility to PSE by all potential students. The private sector would be responsible for the issuance, administration and collection of payments with some public sector aid in the collection role.

An empirical analysis applied to the first undergraduate and professional degree obtained by 1990 graduates results in maximum repayment burdens of $10 \%$ to $12 \%$ of gross incomes for those earning the lowest incomes. The students' and government's shares of the total costs under a PP would be approximately in the same range as the $25 \%$ to $50 \%$ tuition fees under current financing arrangements. Assuming continued high participation rates of graduates and modest growth rates of income leads to a total cost to the public less than the current financing system with students paying $50 \%$ of full fees. A more conservative estimate using 1986 Census data for males and adopting a 1.2 birth per female assumption for females leads to a public sector cost equivalent to the current system with students paying $42 \%$ of full fees. From a direct cost 
point of view neither the public sector nor students would be made worse off by a move to the PP.

Unmeasured benefits of the PP include an incentive structure which promotes the efficient production and delivery of PSE services as well as further cooperation and integration of PSE services among different institutions. The PP achieves the goal of accessibility for all qualified students regardless of income and ensures that concerns about income maintenance do not detract from academic performance.

Implementation of the PP is conceptually straightforward. Both levels of government must agree to the tax deductibility of PSE loan repayments and the default cost of the loans can be allocated among Provinces in proportion to loans made to students attending PSE institutions in that province. This need not imply that Provinces bear the full cost of defaults. The cash and tax transfer components of the Canadian Health and Social Transfer could be adjusted to ensure that the current proportions of Federal and Provincial funding of PSE are maintained. This implies a possible change in the mix of cash and tax points, rather than the level of funding. A more difficult issue concerns the manner in which the long term future outlays for default and tax expenditures are to be financed by early period PSE savings. To the extent that adopting the $\mathrm{PP}$ is approximately revenue neutral to the public sector, further examination of the details the cost sharing between levels of government and financing over the long run is warranted.

\section{References}

Beaujot, R., Gee, E.M., Rajulton, F., \& Ravenera, Z.R. (1995). Family over the life course. Current dempographic analysis. Ottawa, ON: Statistics Canada, No 91-543E Occasional.

Butlin, G. (1995). Adult women's participation rate at a standstill. Perspectives on Labour and Income, Autumn, 30-33, Statistics Canada.

Chapman, C.B. (1994). Income contingent college loans. Journal of Economic Perspectives, 8(4), 206-206.

Constantos, C. \& West. E.G. (1991). Measuring returns from education: Some neglected factors. Canadian Public Policy, 27(2), 127-138.

Council of Ontario Universities. (1992). Financial report of Ontario Universities, 1991-92.

Economic Council of Canada. (1992). A lot to learn: Education and training in Canada. Ottawa, ON: Ministry of Supply and Services, Canada. 
Grindstaff, C.F. (1992). A vanishing breed: Women with large families: Canada in the 1980s. Canadian Studies in Population, 19(2), 145-162.

Hobart, C. (1991). Interest in parenting at the end of the eighties: A study of Canadian students. Canadian Studies in Population, 18(1), 75-100.

Hyatt, D.E., \& Milne, W.J. (1991). Countercyclical fertility in Canada: Some empirical results. Canadian Studies in Population, 18(1), 1-16.

Kesselman, J.R. (1993). Squeezing universities, students, or taxpayers? Issues in designing a Canadian income-contingent loan program. In Institute for Research on Public Policy, Ending the Squeeze on Universities (pp 53-71). Montreal, PQ.

Lefebrve, P. (1995). Investissement dans les enfants. Policy Options, Dec., 11-15.

Macdonald Royal Commission. (1985). Report of the Royal Commission on economic union and development prospects for Canada. Ottawa, ON: Minister of Supply and Services.

Maxwell, J. (1994). More carrots please: Education, training, and fiscal federalism. In K. Banting, D. Brown, \& T. Courchene (Eds.), The future of fiscal federalism, (pp. 217-247). Kingston, ON: Queen's University, School of Policy Studies.

Minister of Human Resources and Development. (1994a). Agenda: Jobs and growth, improving social security in Canada. A discussion paper (The Axworthy Green Paper). Ottawa, ON: Minister of Supply and Services.

Minister of Human Resources and Development. (1994b). Federal support to postsecondary education: A supplementary paper. Ottawa, ON: Minister of Supply and Services Canada.

Nerlove, M. (1976). Some problems in the use of income-contingent loans for the finance of higher education. Journal of Political Economy, 83(1), 157-183.

Ontario Ministry of Colleges and Universities. (1990). Horizons 1989/1990.

Report of the Advisory Council on Adjustment. (1989). Adjusting to win. A.J. de Grandpre (Chairman). Ottawa, ON: Minister of Supply and Services.

Romaniuc A. (1984). Fertility in Canada: From baby-boom to baby-bust. Current demographic analysis. Statistics Canada No. 91-524E Occasional.

Schultz, T.W. (1963). The economic value of education. New York, NY: Columbia University Press.

Stager, D.A. (1989). Focus on fees: Alternative policies for university tuition fees. Toronto, ON: Council of Ontario Universities.

Stager, D., \& Derkach, D. (1992). Simulation model for contingent repayment student assistance plans, in contingent repayment student assistance plans. Toronto, ON: Council of Ontario Universities.

Statistics Canada. (1992). Survey of 1990 Graduates. Ottawa, ON: Minister of Supply and Services. 
Statistics Canada. (1994). Education in Canada 1992-93. (Catalogue 81-229). Ottawa, ON: Minister of Supply and Services.

Statistics Canada. (1995a). Women in Canada: A Statistical Report. (Catalogue 89-503E). Ottawa, ON: Minister of Supply and Services.

Statistics Canada. (1995b). Population projections for Canada, Provinces and Territories, 1993-2016. (Catalogue 95-520, Occasional). Ottawa, ON: Minister of Supply and Services.

Vaillancourt F. (1995). Couples, families, and public policy. Policy Options, Dec., 23-26.

West, E.G. (1993). Ending the squeeze on universities. In S.T. Easton (Ed.), Ending the Squeeze on Universities (pp 11-49). Montreal, PQ: Institute for Research on Public Policy.

West, E.G. (1988). Higher education in Canada. Vancouver, BC: The Fraser Institute.

\section{Notes}

1 A summary of the Australian Higher Education Contribution Scheme and further references can be found in Chapman (1994).

2 West (1993) and before him the Macdonald Royal Commission (1985) recommended that universities be permitted to set differentiated fees.

3 Lower quality educational services would be expected to command lower tuition fees. In the limit, mail-order degrees might well qualify for tuition loans, but repayment of such loans would also be relatively simple. On a more positive note, the increasing possibilities of distance learning may prove to be an access and quality enhancing addition to the traditional PSE institutional offerings.

4 The portion of a loan for tuition might be automatically deposited to the institution in which the student is registered. This differs from the loan system instituted by the Queens' School of Business in which all loans pass through a bank designated by the School. In this case, the School backs the loans.

5 The thirty year repayment period and the $35 \%$ rule are parameters of the PP. The rationale for this parameterization is discussed in the feasibility analysis.

6 Ontario Ministry of Colleges and Universities (1989), page 2.

7 Budget figures in this section are taken from the Financial Report of Ontario Universities, 1991-92. Given the dominant weight of Ontario in Canadian universities, we presume that these figures are good proxies for the Canadian average costs.

8 Average fees could be reduced by $30 \%$ to $50 \%$ depending upon the allocation of research and other costs in the operating budgets. 
9 This contrasts with the $\$ 21,402$ threshold used by Stager and Derkach (1992), p. 9.

10 A lump sum of $\$ 9000$ is also allowed as a deduction from income for tax purposes to account for the personal tax credit as well as other miscellaneous tax credits. This amount is most appropriate for income earners in the lowest tax bracket.

11 The total dollar value of default is important for policy purposes. This treatment of these two groups would tend to over-estimate the dollar value of defaults. The Survey does not distinguish between Medical degrees and Health Science and related degrees but reported earnings were the highest of all groups.

12 CANSIM series D747018, the increase in wage rates, all industries, non-cola is used for this adjustment. Earnings are increased by $9.7 \%$.

13 Stager and Derkach (1992), page 18 also note this problem.

14 Grindstaff (1992), Hobart (1991), and Romaniuc (1991) discuss fertility in Canada. Higher education levels, age of the mother at first child, earnings and social acceptance of female workforce participation tend to reduce fertility.

15 Beaujot, et al. (1991) in analysing the 1984 Canadian Fertility Survey report that the average number of children in 1984 for women with some university education was 0.96 .

16 Lefebvre (1995) and Vaillancourt (1995) both argue for pre-school programs for children starting at age three. Regulations in the iormal child care sector differentiate between infants and toddlers based on an age of one and one half years.

17 While deductibility of capital and interest expenses is not an expense to the government, the ICR would change the tax revenue of the government in a significant way and is therefore included in the analysis.

18 Nerlove (1976) discusses the issue of opting out in very great detail and in the context of the Yale loan plan. Although the Yale plan is self financing, adverse selection is seen as a real problem, good students can go elsewhere and hence raise the premium. Of course, weaker students is not a problem for Yale and the Yale experience might not extend to all universities.

19 Minister, Human Resources and Development, (1994b).

20 Note that even a tax-based ICR would require some agency tasked with the collection of accounts in default.

21 The intergenerational transfer involved takes on a greater significance when considered as a part of the total transfers which might be expected to 
occur in the provision of pension and old age income security. See Courchene (1994) Chapter 3 . In the longer run, welfare gains due to decreased taxes may accrue to the extent that tax expenditures are less welfare reducing than tax collections. See Constantos and West (1991) for a recent evaluation of the welfare cost of taxation as it relates to the cost of education. 